\title{
ECOLOGICAL ASSESSMENT OF FISH CULTURE WATER BODIES AROUND DHAKA CITY, BANGLADESH
}

\author{
Pronob Kumar Mozumder*, Habiba Sultana \\ Bipul Chandra Biswas ${ }^{1}$ and Md. Abdur Rob Mollah \\ Faculty of Biological Sciences, Department of Zoology, University of Dhaka \\ Dhaka 1000, Bangladesh
}

\begin{abstract}
This study was conducted during the period November, 2014 - June, 2015 in two urban fish culture pond, at Kalshi and Namapara area of Dhaka city. These ponds are connected to Baunia canal. Water samples were collected seasonally for water quality and zooplankton analyses. Except DO all other measured water quality parameters ( $\mathrm{pH}$, TDS, TSS, total ammonia-N, total nitrite$\mathrm{N}$, total nitrate- $\mathrm{N}$, total phosphate, total sulphate, alkalinity and hardness) were found higher in water. A total of 10 heavy metals $(\mathrm{Zn}, \mathrm{Fe}, \mathrm{Pb}, \mathrm{Cd}, \mathrm{Al}, \mathrm{As}, \mathrm{Cu}, \mathrm{Na}$, $\mathrm{Mn}$ and $\mathrm{Cr}$ ) were measured for determining its concentrations in waters in two seasons. A total of 10 zooplankton species were recorded at Kalshi during the study period and on an average, the density of zooplankton in dry season and in wet season were estimated to be 1386 indiv./L and 244 indiv./L respectively. On the other hand, a total of 19 zooplankton species were identified from Namapara water body and on an average, the density of zooplankton in dry season and in wet season were estimated to be 1760 indiv/L and 343 indiv./L respectively. Bacteriological analysis included the total plate count (TPC), total coliform (TC) and total faecal coliform (TFC) counts in waters, both in wet and dry seasons. In general, water qualities of the studied fish culture water bodies are highly deviated from the permissible standard levels of Environment conservation rules, 1997 and unsuitable for fish culture from fish health point of view. The measured high levels of metals in waters are likely to bioaccumulate in fish body. High abundance of bacterial flora in fish culture waters is also likely to be associated with fish health and may cause enteric diseases. Therefore, fish culture in these urban water bodies is likely pose potential health risks for human through consuming these fishes.
\end{abstract}

Key words: Zooplankton, heavy metal, bacteriological.

\section{INTRODUCTION}

Although, the aquaculture activities in urban areas in Bangladesh are not expected to expand to a commercial scale because of higher population densities

*Author for corresponding: <pronob7du@gmail.com>

(c)2021 Zoological Society of Bangladesh DOI: https://doi.org/10.3329/bjz.v49i2.56263 
and scarcity of enough land area, however, recent field observations indicate that fish are extensively cultured in all available water bodies within Dhaka City, particularly in the peripheral areas, having deep flooded areas. Scarcity of fish supply and high fish price spurred the cultivation of fish in the urban water bodies. Among the water bodies inside the city, some government-owned large ponds and lakes are important culturable water areas. Encroached canals and enclosed floodplain areas having perennial waters are extensively used for fish culture. Recent observations shows that water bodies in Pagla areas (WASA Sewerage Plant), Matuail areas, Khilkhet areas, Bauniabandh areas, Kalshi, Mirpur beribandh areas, Gabtoli floodplain areas, Rampura floodplain areas extensively used for fish culture. In fact, every available perennial water bodies in and around Dhaka City are used for fish culture. This culture practices are either done in encroached water areas or in privately owned water bodies. As per local accounts, this fish culture practice is undertaken by local influential people. Fish are locally marketed and often in live condition. The culture practice is very flexible and varies from to place to place and farms to farms. It is evident that water bodies in and around of Dhaka Metropolitan City is polluted with different kinds of industrial pollutants and various anthropogenic activities (Dewan et al., 2012). There is a scarcity of information on the water quality of such water bodies that used to use as fish culture and other aspects upon which arguments could be based against the culture of fish in urban areas. Although, water quality data are available on urban areas in general, not specific to fish culture water bodies. Therefore, there is a need to determine the water quality of fish culture water bodies covering a wide range of relevant parameters, ranging from physic-chemical to heavy metals. Food contamination by pathogenic bacteria is a great concern to public health. The contents of coliform bacteria reported based on analysis of some water sample of Dhaka City signifies the extent of the problem. Therefore, it is also very important to know the bacterial load, at least on coliform bacteria (Total plate count, total faecal coliform and total coliform) in waters of the urban fish culture water bodies. Pollution of aquatic habitat has adverse impacts on biodiversity. It will be equally important to investigate this aspect, particularly in fish culture conditions. Zooplankton is considered as a good indicator of aquatic pollution as they immediately respond to pollution and zooplankton plays an important role in fish growth (Mozumder et al., 2014). Therefore, study of zooplankton (qualitative and quantitative) will give an idea on the extent of the pollution and its impact on biodiversity of the fish farms. Considering the above matters, the study was undertaken with a view to understanding the problem and generating data necessary to assess the culture practice, its impacts and potential health 
risks associated with the consumption of fish raised in urban water bodies, which will ultimately help to take pragmatic decisions on the issue with the specific objectives. The objectives of the study were to assess the water qualities, composition and abundance of zooplankton and bacterial and heavy metal contamination of fish culture waters.

\section{MATERIAL AND METHODS}

This study was carried out during the period of November, 2014 to June, 2015 in two selected sites within the Dhaka Metropolitan city, namely the Kalshi area and the Namapara near the Dhaka Cantonment area.

Water Sampling and Analysis for Physico-chemical parameters: The samples were collected from 3 selected spots of each selected water body in duplicate. Water samples were taken from 6 inches beneath the water surface of each sampling spot between 9-12 am on each sampling day using sampling bottles. Some water parameters were analyzed onsite. Requisite amount of water samples were transported to laboratory in cool box for analyzing the rest of the water parameters. Samples were collected following standard methods (Gupta, 2007). Physico-chemical parameters of water were analyzed in the laboratory by following $\mathrm{HACH}$ standard methods.

Collection of samples for zooplankton study: For zooplankton sample collection, 50 liters of water was filtered successively through $64 \mu \mathrm{m}$ mesh nylon nets (Millipore Corp., Bedford, MA), and $20 \mathrm{ml}$ of the concentrates zooplankton sample was collected initially as a crude measure of zooplankton. The collected zooplankton samples were fixed in $5 \%$ buffer formaldehyde solution. For qualitative and quantitative study, zooplankton samples were examined under a compound microscope (Olympus, Model-CH30RF200, Japan) in a Sedge wickRafter cell. Quantitative analysis was followed by the total count method of Welch (1948). Identification was made following Ward \& Whipple (1959), Tonapi (1960), Mellanby (1975), Bhouyain and Asmat (1992) and Ali and Chakrabarty (1992).

Microbiological Analysis: Water samples were collected in plastic bottles sterilized with alcohol. Nutrient agar (NA), Mac Conkey agar and MFC agar medium were used for the enumeration of the Total plate count (C.F.U/ml), Total coliform (C.F.U/ml) and Total Faecal coliform (C.F.U/ml) of the sample water respectively. Spread plate technique (Sharp and Lyles, 1969) were used for the enumeration and isolation of bacteria (APHA 1998). The Nutrient agar and Mac Conkey agar medium (inoculated plates) were incubated at $37^{\circ} \mathrm{C}$ and $\mathrm{MFC}$ inoculated plate was incubated at $44.5^{\circ} \mathrm{C}$ for $24 \mathrm{hrs}$ in an incubator (Memmert, 
Germany). After $24 \mathrm{hrs}$ of incubation the plates having discrete colonies were counted by back calculation method.

Heavy metal analysis: Samples were collected in 1L bottles. 2-3 drops $\mathrm{HNO}_{3}$ were added in the samples for acidification. Then samples were analyzed by the Atomic Absorption Spectrophotometric (AAS) method (Model- SpectrAA 220FS)

\section{RESULTS AND DISCUSSION}

Physico-chemical Parameters of Waters: Colour of the water of the study areas ranged from $63 \mathrm{Pt}$-Co to $95 \mathrm{Pt}-\mathrm{Co}$ (Table 1). Water colour may influence on abundance of plankton community. Water temperature of the two study areas ranged between 22 to $32.2^{\circ} \mathrm{C}$ which was favourable for aquatic life. Turbidity of the study areas ranged from 43 to 62 FTU (Table 1). Alam (2014) found 11 to 13 NTU in Hatir jheel Lake that remains in the standard value. During study, $\mathrm{pH}$ value varied from 7.09 to 8.34 .

The conductivity of waters measured in the study areas varied from $517 \mu \mathrm{S} / \mathrm{cm}$ to $613 \mu \mathrm{S} / \mathrm{cm}$ (Table 1 ). The TDS values of the study areas varied between $250 \mathrm{mg} / \mathrm{L}$ to $300 \mathrm{mg} / \mathrm{L}$. Total Suspended Solids (TSS values of the study areas ranged between $34 \mathrm{mg} / \mathrm{L}$ to $67 \mathrm{mg} / \mathrm{L}$. Mondol et al., (2011) observed TDS level between 303.1 to $483.3 \mathrm{mg} / \mathrm{L}$, conductivity level between 835.9 to $852.7 \mu \mathrm{S} / \mathrm{cm}$ and TSS level between 68.9 to 1379 in the water of Tejgaon area of Dhaka city. Salinity levels in the present study ranged from 0.27 to $0.3 \%$ ). These levels are problematical for fish culture (Alabaster and Llyod, 1980). The DO levels in the present study ranged from 2.9 to $8.6 \mathrm{mg} / \mathrm{L}$ which was suitable for fish culture. Bhuiyan et al., (2011) found DO level $4.72 \mathrm{mg} / \mathrm{L}$ and $4.95 \mathrm{mg} / \mathrm{L}$ at Ashulia and Aminbazar open water of Dhaka city respectively. During study, Phosphate ranged from 8.9 to $30.7 \mathrm{mg} / \mathrm{L}$ (Table 1). Phosphate is considered as indicative of productivity of fish ponds (Boyd, 1982). Ammonia-N ranged from 1.24 to $12.8 \mathrm{mg} / \mathrm{L}$ during study period. Mozumder et al., (2014) found ammonia variation from $0.3 \mathrm{mg} / \mathrm{L}$ to $0.6 \mathrm{mg} / \mathrm{L}$ in a fish culture pond in Manikganj. In spite of this high level of ammonia during study, fish grow well, probably because of that toxic effects of ammonia is reduced by some other chemicals. Nitrate- $\mathrm{N}$ ranged from 0.5 to $4.6 \mathrm{mg} / \mathrm{L}$ ) in the present study. In the present study, Nitrite-N level ranged from 0.105 to $0.481 \mathrm{mg} / \mathrm{L}$. During study total sulphate and free chlorine ranged from 3 to $13 \mathrm{mg} / \mathrm{L}$ and 0.08 to $0.16 \mathrm{mg} / \mathrm{L}$ respectively. In the present study COD ranged from 35 to $105 \mathrm{mg} / \mathrm{L}$ (Table 1) that were very high than the standard value set by ECR'97. During study BOD ranges from 39 to $82 \mathrm{mg} / \mathrm{L}$. The permissible limit of BOD for fish culture is 6 $\mathrm{mg} / \mathrm{L}$ or less $(\mathrm{GoB}$, 
Table 1. Measured Physico-chemical Parameters of Water collected from Kalshi and Namapara

\begin{tabular}{|c|c|c|c|c|c|c|}
\hline \multirow{2}{*}{$\begin{array}{l}\text { Physico-chemical } \\
\text { Parameters }\end{array}$} & \multicolumn{2}{|c|}{ Kalshi } & \multicolumn{2}{|c|}{ Namapara } & \multirow{2}{*}{$\begin{array}{c}\text { Water quality } \\
\text { standard level } \\
\text { (ECR, 1997) }\end{array}$} & \multirow{2}{*}{$\begin{array}{c}\text { Water } \\
\text { quality } \\
\text { standard for }\end{array}$} \\
\hline & $\begin{array}{c}\text { Dry } \\
\text { season }\end{array}$ & $\begin{array}{c}\text { Wet } \\
\text { season }\end{array}$ & $\begin{array}{c}\text { Dry } \\
\text { season }\end{array}$ & $\begin{array}{c}\text { Wet } \\
\text { season }\end{array}$ & & \\
\hline Colour (Pt Co) & 63 & 88 & 79 & 95 & 15 & \\
\hline Temperature $\left({ }^{\circ} \mathrm{C}\right)$ & 22.8 & 31 & 22 & 32.2 & $20-30$ & \\
\hline Turbidity (FTU) & 44 & 62 & 43 & 45 & 10 & \\
\hline $\mathrm{pH}$ & 7.09 & 8.02 & 8.34 & 8.13 & $6.5-8.5$ & Fisheries \\
\hline Conductivity $(\mu \mathrm{S} / \mathrm{cm})$ & 613 & 564 & 606 & 517 & $800-1000$ & \\
\hline TDS (mg/L) & 300 & 274 & 293 & 250 & 250 & \\
\hline TSS(mg/L) & 39 & 53 & 67 & 34 & 12 & \\
\hline Salinity (\%) & 0.3 & 0.27 & 0.29 & 0.27 & & \\
\hline Dissolved & 7.09 & 6.45 & 8.6 & 2.9 & 5 or more & Fisheries \\
\hline \multicolumn{7}{|l|}{ Oxygen (mg/L) } \\
\hline $\begin{array}{l}\text { Total Phosphate } \\
\text { (mg/L) }\end{array}$ & 8.9 & 12.7 & 16.8 & 30.7 & 6 & \\
\hline $\begin{array}{l}\text { Ammonia- } \\
\text { Nitrogen(mg/L) }\end{array}$ & 1.24 & 11.3 & 11.6 & 12.8 & $0.02-1.2$ & Fisheries \\
\hline $\begin{array}{l}\text { Total Nitrate- } \\
\text { Nitrogen (mg/L) }\end{array}$ & 4.6 & 0.8 & 2.4 & 0.5 & 10 & \\
\hline $\begin{array}{l}\text { Total Nitrite-Nitrogen } \\
(\mathrm{mg} / \mathrm{L})\end{array}$ & 0.481 & 0.105 & 0.304 & 0.203 & 0.03 & \\
\hline $\begin{array}{l}\text { Total Sulphate } \\
\text { (mg/L) }\end{array}$ & 6 & 3 & 13 & 5 & 400 & \\
\hline $\begin{array}{l}\text { Total Free Chlorine } \\
(\mathrm{mg} / \mathrm{L})\end{array}$ & 0.08 & 0.16 & 0.13 & 0.11 & 0.2 & \\
\hline Total COD (ppm) & 95 & 35 & 105 & 41 & & \\
\hline $\begin{array}{l}\mathrm{BOD}_{5}(\mathrm{mg} / \mathrm{L}) \text { for } 5 \\
\text { days }\end{array}$ & 82 & 53 & 75 & 39 & 6 or less & Fisheries \\
\hline Hardness(mg/L) & 175 & 120 & 75 & 80 & & \\
\hline Alkalinity $(\mathrm{mg} / \mathrm{L})$ & 85 & 226 & 95 & 245 & & \\
\hline
\end{tabular}

ECR, 1997). So the BOD values obtained in the present study indicated that both the water bodies were unsuitable for fish culture. These BOD values also indicate very high level of organic pollution. Hardness levels ranged from 75 to $175 \mathrm{mg} / \mathrm{L}$ (Table 1) in the present study. Hardness level of $170 \mathrm{mg} / \mathrm{L}$ is termed as good quality water (Khan et al., 1990). Hasan et al., (2009) observed hardness levels ranged from 91.94 to $164.99 \mathrm{mg} / \mathrm{L}$ in Buriganga river. Alkalinity of the studied water bodies varied from 85 to $245 \mathrm{mg} / \mathrm{L}$. Similar results observed by Hasan et al., (2009). Highly productive water bodies should have more than $100 \mathrm{mg} / \mathrm{L}$ alkalinity (Allikunhi, 1957). From the above observation, it can be said that physico-chemical parameters of studied aquatic environments were not favourable for normal growth of fish and life of the aquatic environments because most of the water quality parameters were above the standard value set by ECR'97 for fish culture.

Seasonality and abundance of zooplankton: On an average, at Kalshi, the density of zooplankton in dry season was estimated to be 1386 indiv./L in dry and 244 (indiv./L) in wet season.(Table 2). Cyclops sp. (1008 indiv./L) dominated the abundance, followed by Moina sp (87 indiv.//L) and Mesocyclops 
sp.(58 indiv.//L). The results show that abundance of zooplankton varied greatly between dry (1386 indiv./L) and wet (244 indiv./L) seasons. In case of Namapara water body, the average density of zooplankton was calculated to be 1790 indiv/L for dry season and 343 indiv./L for wet season. The most abundant species was Brachiophonus calyciflorus (860 indiv.//L), followed by Diaphonosoma sp (356 indiv /L) and Cyclops sp. (106 indiv/ L). As with Kalshi, the zooplankton community of Namapara water body also showed strong seasonal variation, being highest in dry season. Rotifera species abundance from both the sites (Kalshi and Namapara) were highest compared to other groups and it indicates favourable environmental condition. Mozumder et al., (2012) observed highest abundance of rotifera from both Mathbaria pond $(64.86 \%)$ and Bakerganj pond (60.98\%) of Barishal division of Bangladesh. During dry season, high concentrated nutrient content in the water bodies may resulted in increased the density of zooplankton.

Table 2. Composition and density (Number/L) of zooplankton recorded from Namapara water body

\begin{tabular}{|c|c|c|c|c|c|}
\hline \multirow[t]{2}{*}{ Group } & \multirow[t]{2}{*}{ Species name } & \multicolumn{2}{|c|}{ Namapara } & \multicolumn{2}{|c|}{ Kalshi } \\
\hline & & $\begin{array}{c}\text { Dry } \\
\text { season }\end{array}$ & $\begin{array}{c}\text { Wet } \\
\text { season }\end{array}$ & $\begin{array}{c}\text { Dry } \\
\text { season }\end{array}$ & Wet season \\
\hline \multirow{4}{*}{ PROTOZOA } & Centropuxis sp. & & 4 & & \\
\hline & Difflugia sp. & 5 & & 44 & \\
\hline & Unidentified & & 2 & & \\
\hline & Asplanchna priodonta & 15 & & & 23 \\
\hline \multirow{11}{*}{ ROTIFERA } & Brachionus angularis & 96 & 15 & 29 & 3 \\
\hline & Brachionus calyciflorus & 860 & 107 & 29 & 30 \\
\hline & Hexarthra sp. & & 26 & & \\
\hline & Brachionus forficula & 5 & & 15 & 2 \\
\hline & Brachionus falcatus & 20 & & & \\
\hline & Brachionus urceolaris & 68 & 2 & & \\
\hline & Brachionus quadridentatus & 24 & 4 & & \\
\hline & Filinia longiseta & 10 & 9 & & \\
\hline & Platyius patula & 5 & & & \\
\hline & Polyarthra sp. & 17 & & & 5 \\
\hline & Unidentified & 5 & 2 & 72 & \\
\hline COPEPODE & Nauplius & 15 & 9 & 29 & 6 \\
\hline NAUPLII & Metanauplius & & & & 3 \\
\hline \multirow[t]{3}{*}{ COPEPODA } & Cyclops sp. & 106 & 33 & 1008 & 114 \\
\hline & Mesocyclops sp. & 24 & 4 & 58 & 51 \\
\hline & Unidentified & & 4 & & \\
\hline \multirow[t]{3}{*}{ CLADOCERA } & Diaphanosoma sp. & 356 & 71 & & 5 \\
\hline & Moina sp. & 154 & 27 & 87 & 2 \\
\hline & Unidentified & & 2 & 15 & \\
\hline \multirow[t]{2}{*}{ OSTRACODA } & Cypris sp. & & 20 & & \\
\hline & Heterocypris sp. & 5 & 2 & & \\
\hline \multicolumn{2}{|c|}{ Total Zooplankton /L } & 1790 & 343 & 1386 & 244 \\
\hline
\end{tabular}


Bacterial Contaminations: In the present study, total plate counts varied from $6.6 \times 10^{6}(\mathrm{cfu} / \mathrm{ml})$ to $11.8 \times 10^{6}(\mathrm{cfu} / \mathrm{ml})$. Similarly, total faecal coliform counts ranged from $50(\mathrm{cfu} / \mathrm{ml})$ to $2.5 \times 10^{2}(\mathrm{cfu} / \mathrm{ml})$ and total coliform counts fluctuated from $0.1 \times 10^{4}(\mathrm{cfu} / \mathrm{ml})$ to $0.9 \times 10^{5}(\mathrm{cfu} / \mathrm{ml})$ (Table 3). A level of faecal coliform of below $10 / \mathrm{ml}$ of water is suitable for pond aquaculture (WHO, 1989). The loads of different bacteria observed in water samples during study period were higher than recommended value for aquaculture. Mandal et al., (2009) found significantly higher density of total bacterial count, total coliform count and total faecal coliform count in the gill and intestine than that of muscle of Nile tilapia harvested from pond. Parveen (2008) found $2.4 \times 10^{4} / 100 \mathrm{~mL}$ total coliform and $2.4 \times 10^{4} / 100 \mathrm{~mL}$ faecal coliform in pond water of Dhaka city. During study, the levels of bacterial contamination of water of the fish culture system was worrying, because many of the bacteria would be associated with fish body and may cause enteric diseases to human.

Table 3. Bacterial counts (cfu/ $\mathrm{ml}$ ) of water samples of Kalshi and Namapara water body

\begin{tabular}{lllll}
\hline Parameters & \multicolumn{2}{c}{ Kalshi } & \multicolumn{2}{c}{ Namapara } \\
\cline { 2 - 5 } & Dry season & Wet season & \multicolumn{1}{c}{ Dry season } & Wet season \\
\hline Total plate count $(\mathrm{cfu} / \mathrm{ml})$ & $7.1 \times 10^{6}$ & $11.8 \times 10^{6}$ & $6.6 \times 10^{5}$ & $10.7 \times 10^{5}$ \\
Total Faecal coliform $(\mathrm{cfu} / \mathrm{ml})$ & $1 \times 10^{2}$ & $2.5 \times 10^{2}$ & 50 & $1.6 \times 10^{2}$ \\
Total coliform $(\mathrm{cfu} / \mathrm{ml})$ & $0.9 \times 10^{5}$ & $3 \times 10^{5}$ & $7.0 \times 10^{2}$ & $0.1 \times 10^{4}$ \\
\hline
\end{tabular}

Table 4: Seasonal variation in contamination level of heavy metals in surface water of Kalshi and Namapara

\begin{tabular}{lllll}
\hline Heavy Metals & \multicolumn{2}{c}{ Kalshi } & \multicolumn{2}{c}{ Namapara } \\
\cline { 2 - 5 } & Dry Season & Wet Season & Dry Season & Wet Season \\
\hline Total Zinc $(\mathrm{mg} / \mathrm{L})$ & $\mathrm{bdl}$ & $\mathrm{bdl}$ & $\mathrm{bdl}$ & $\mathrm{bdl}$ \\
Total Iron $(\mathrm{mg} / \mathrm{L})$ & 92.88 & 129.72 & 93.42 & 71 \\
Total Lead $(\mathrm{mg} / \mathrm{L})$ & 0.9 & 0.91 & 0.8 & 0.74 \\
Total Cadmium $(\mathrm{mg} / \mathrm{L})$ & 0.081 & 0.07 & 0.07 & 0.08 \\
Total Aluminium $(\mathrm{mg} / \mathrm{L})$ & 29.55 & 39.39 & 19.32 & 23.25 \\
Total Arsenic $(\mu \mathrm{L} / \mathrm{L})$ & 6.74 & 5.98 & 18.32 & 12.5 \\
Total Copper $(\mathrm{mg} / \mathrm{L})$ & $\mathrm{bdl}$ & $\mathrm{bdl}$ & $\mathrm{bdl}$ & $\mathrm{bdl}$ \\
Total Sodium $(\mathrm{mg} / \mathrm{L})$ & 95.11 & 98.43 & 110.7 & 95.11 \\
Total Manganese $(\mathrm{mg} / \mathrm{L})$ & 0.19 & 0.26 & 0.12 & 0.13 \\
Total Chromium $(\mathrm{mg} / \mathrm{L})$ & 0.07 & 0.09 & 0.05 & 0.06 \\
\hline
\end{tabular}

Heavy Metals: Except, copper and zinc, all the heavy metals measured showed excessive concentrations, particularly that of iron, aluminium and lead (Table 4). These levels are toxic and may cause various diseases (Alabaster and Llyod, 1980; Rand and Petrocelli, 1985). Appreciable levels of arsenic were noted in waters from both water bodies. DPHE (2013) also recorded high levels of 
heavy metals in waters from Gulshan Lake, Dhaka. Similarly, a number of studies also reported high levels of heavy metals heavy metals in water from Dhaka (Rahman et al., 2012 and Islam et al., 2012). Many metals measured in this study have the ability to bioaccumulate in animal tissues. (Rand and Petrocelli, 1985). Therefore, it is very likely that higher levels of these heavy metals would be found in fishes cultured in these water bodies and likely to cause diseases in human when consumed.

\section{CONCLUSION}

The assessment shows that the waters of the fish culture system are unsuitable for irrigation, fish culture and recreational purposes, when compared with the country standards. All the heavy metals are toxic to fish and human at higher concentrations. These heavy metals bioaccumulate in animal tissues and likely to be in fish tissue culture in this water and thus affect the human health when consumed. In spite of the unsuitable water quality for life forms, zooplankton community was present in appreciable numbers, indicating that the waters are fertile. The increased number of zooplankton in waters is indicative of the presence of high content of organic matters. The bacteriological study showed high level of bacterial contamination of culture system water and likely to be associated with fish body, and thus may cause enteric diseases when consumed by human. It is concluded that the water bodies are highly polluted and consumption of fish that were cultured in these waters is very likely to pose health risks.

\section{LITERATURE CITED}

ALABASTER, J. S. and LLOYD, R. 1980. Water Quality Criteria of Freshwater Fish. Buttersworth. Inc. Boston, Massachusetts. 297pp.

ALAM, M. S. 2014. Assessment of Water Quality of Hatirjheel Lake. International Journal of Technology Enhancements and Emerging Engineering Research. 2 (6):97-100.

ALI, S. and CHAKRABARTY, T. 1992. Bangladesher Mitha Panir Amerudandi Prani (A Book of Freshwater Invertebrates of Bangladesh). 1st edition. Bangla Academy, Dhaka, Bangladesh. pp. 176.

ALKUNHI, K. H. 1957. Fish Culture in India. Farm Bull No.20, Indian Coun. Agr. Res. New Delhi. 144pp.

APHA (American Public Health Association). 1998. Standard Methods for Examination of Water and Wastewater. $20^{\text {th }}$ edition. Washington DC. 874pp.

BHOUYAIN, A. M and ASMAT, S. M. 1992. Freshwater Zooplankton from Bangladesh. $1^{\text {st }}$ edition. pp. 137. 
BHUIYAN, M. A., RAKIB, M. A., DAMPARE, S. B., GANYAGLO, S., SUZUKI, S. 2011. Surface water quality assessment in the central part of Bangladesh using multivariate analysis. KSCF J. Civil Eng. 15(6): 995-1003.

BOYD, C. E. 1982. Water quality management for pond fish culture. Elsevier, 87-113.

DPHE (Department of Public Health Engineering). 2013. Water Quality Assessment Report on Gulshan Lake. DPHE Central Laboratory, Mohakhali, Dhaka.

DEWAN, A. M., KABIR, M. H., NAHAR, K., and RAHMAN, M. Z. 2012. Urbanization and environmental degradation in Dhaka metropolitan area of Bangladesh. Int. J. Environment and Sustainable Development. 11(2): 118-147.

ECR (Environment Conservation Rules). 1997. Department of Environment, Ministry of Environment and Forests, Government of Bangladesh (GoB).

GUPTA, P. K. 2007. Methods in environmental analysis: water, soil and air. Agrobios. pp.5-127.

HASAN, I., RAJIA, S., KABIR, K. A. and LATIFA, G. A. 2009. Comparative study on the water quality parameters in two rural and urban rivers emphasizing on the pollution level. Global J. Environ. Res. 3 (3): 218-222.

KHAN, S. M. M. H., AZIZ, K. M. S., MORSHED, M. G. and SHAFI, M. 1990. Seasonal variations in physico-chemical conditions of Dhanmondi Lake Water. Bangl. J. Zool. 18(1):61-66.

MANDAL, S. C., HASAN, M., RAHMAN, M. S., MANIK, M. H., MAHMUD, Z. H. and ISLAM, M.D.S. 2009. Coliform bacteria in Nile Tilapia, Oreochromis niloticus of shrimp-gher, pond and fish market. World J. Fish \&Marine Sci. 1(3): 160-166.

MELlANBY, H. 1975. Animal Life in Freshwater. $6^{\text {th }}$ ed. Trowbridge and Esher, Fedowood, Burn Ltd. pp. 308.

MONDOL, M.N., CHAMON, A.S., FAIZ, B., and ELAHI, S.F. 2011. Seasonal variation of heavy metal concentrations in water and plant samples around Tejgaon industrial area of Bangladesh. J. of Bangladesh Academy of Science. 35(1): 19-41.

MOZUMDER, P.K., NAHAR, S., NASER, M.N., ALAM, M., HUQ, A., SACK, R.B., and COLWELL, R.R. 2012. Species composition of limnetic zooplankton from the southern coastal areas (Mathbaria and Bakerganj) in Bangladesh. J. Asiat. Soc. Bangladesh, Sci. 38(1):111-117.

MOZUMDER, P.K., NASER, M.N and AHMED, A.T.A. 2014. Abundance of zooplankton and physicochemical parameters of a polyculture fish pond of Manikganj, Bangladesh. Bangladesh J. Zool. 42(1): 67-76.

PARVEEN, S.A. 2008. Microbial contamination of water in around Dhaka city. Bangladesh J. Sci. Ind. Res. 43(2): 273-276.

RAHMAN, A., ZAFOR, M.A. and KAR, S. 2012. Analysis and composition of surface water quality parameters in and around Dhaka city. International Journal of Civil Engineering and Technology (IJCIET).3(2):7-15. 
ISLAM, M. S., TUSHER, T. R., MUSTAFA, M. and MAHMUD, S. 2012. Effects of solid waste and industrial effluents on water quality of Turag river at Konabari industrial area, Gazipur, Bangladesh. J. Environ. Sci. \& Natural Resources. 5(2): 213 - 218.

RAND, G. M. and PETROCELLI, S. R. 1985. Introduction. In: Fundamentals of Aquatic Toxicology. Hemisphere Publishing Corporation .Washington, N.Y., London. pp. 1-28.

SHARP, M. S. and LYLES, S. T. 1969. Laboratory instruction in biology of microorganisms. Saint Lois the C V Mosley Company, St. Louis. pp. 23-25.

TONAPI, G.T. 1960. Freshwater Animal in India (An Ecological Approach). Oxford and IBH Publishing Co., New Delhi. pp. 341.

WARD, H. B. and WHIPPLE, G. C. 1959. Freshwater Biology. $2^{\text {nd }}$ edn. (Ed., Edmonson, W. T.), John Willy and Sons Inc., New York, London, 1248 pp.

WELCH, P. S. 1948. Limnological Methods. McGraw- Hill Book Co.Inc., New York. 381 pp.

WHO. 1989. Health Guidelines for the use of Wastewater in agriculture and Aquaculture. WHO Technical Report Series, Number 778. Geneva, Switzerland.

(Manuscript received on 20 August 2020 revised on 25 August, 2021) 